\title{
USING OF PROTEIN-CONTAINING PLANT GREEN MASS SEMI-PRODUCTS IN THE RECIPLES OF CULINARY PRODUCTS
}

\author{
L. Solodko \\ National University of Food Technologies
}

\begin{tabular}{l}
$\quad$ Key words: \\
Proteinaceous half- \\
products \\
Culinary products \\
Plant green mass \\
Amino acids composition \\
\hline
\end{tabular}

Article history:

Received 10.05.2018

Received in revised form

30.05.2018

Accepted 14.06.2018

Corresponding author:

L. Solodko

E-mail:

npnuht@ukr.net

\begin{abstract}
The possibility of using proteinaceous semi-products from the green mass of plants in recipes of combined culinary products, which combines raw materials of animal and vegetable origin: stuffed cabbages with rice and meat and buckwheat puddings with cheese is considered in the article. The dried protein-containing semi-products from the green mass of plants is a valuable food raw material, rich in physiologically functional food ingredients: proteins (20 - 25\%), fiber, mineral compounds, some vitamins and substances with antioxidant activity. All data based on the literary sources and own researches. The rational dosage of protein-containing semi-finished products in the manufacture of culinary products, which comprise: $3,0 \ldots 3,3 \%$ and $10 \ldots 11,5 \% \%$ to the weight of semi-finished products for stuffed cabbages and buckwheat puddings respectively was substantiated. Amino acid composition was determined for developed combined culinary products in comparison with control samples. The results have shown the presence of all essential amino acids. The amino acid scores for eight key essential amino acids, frequently deficient in mixed human diet, and essential amino acid index were calculated according to FAO standards for essential amino acids. Therefore, the results suggested that combined investigated culinary products are appropriate for use in balanced diets.

It has been shown that the introduction of proteincontaining semi-products from the green mass of plants to the designed recipes contributes to the increase of the biological value of culinary products and provides additional functional properties. The consumption of the developed combined culinary products provide daily need of men in vitamin $\mathrm{C}$ - by $19.5 \ldots 39,5 \%$, $\beta$-carotene - by $28 \ldots 67,6 \%$, in calcium - by $10.1 \ldots 23,9 \%$, in flavonoids - by $32.6 \ldots 56,3 \%$ and proteins in average by $27,6 \ldots 46,5 \%$. The results of researching of organoleptic, physical and chemical parameters of the developed products confirm the expediency of using protein semi-products from the green mass of agricultural and wild plants in the recipes of combined culinary products.
\end{abstract}

DOI: $10.24263 / 2225-2924-2018-24-3-26$ 


\title{
ВИКОРИСТАННЯ БІЛОКВМІСНИХ НАПІВФАБРИКАТІВ ІЗ ЗЕЛЕНОЇ МАСИ РОСЛИН У РЕЦЕПТУРАХ КУЛІНАРНИХ ВИРОБІВ
}

\author{
Л.М. Солодко \\ Національний університет харчових технологій
}

У статті розглянуто можливість використання білкових напівфабрикатів із зеленої маси рослин у рещептурах комбінованих кулінарних виробів, в яких поєднано сировину тваринного та рослинного походження: голубиів з рисом і м'ясом та крупеника гречаного з сиром. Висушені білоквмісні напівфабрикати із зеленої маси рослин є иінною харчовою сировиною, багатою на фізіологічно функиіональні харчові інгредієнти: білки (20-25\%), харчові волокна, мінеральні сполуки, низку вітамінів і речовин з антиоксидантною активністю.

На основі літературних даних і власних досліджень обтрунтовано раціональні дозування білоквмісних напівфабрикатів при виготовленні кулінарних виробів, які складають: 3,0...3,3\% та 10...11,5\% \% до маси напівфабрикату для голубиів і крупеника відповідно. Визначено амінокислотний склад білків розроблених комбінованих кулінарних виробів порівняно з контрольними зразками. Результати показали наявність усіх незамінних амінокислот. Відповідно до стандартів ФАО були розраховані амінокислотний скор $і$ коефіиієнти для восьми ключових незамінних амінокислот, що часто є дефіцитними в харчуванні людини. Результати дослідження підтвердили доиільність використання комбінованих кулінарних виробів у збалансованому харчуванні.

Показано, щзо введення білоквмісних напівфабрикатів із зеленої маси рослин до проектованих рещептур сприяе підвищенню біологічної цінності кулінарної продукиії та надає додаткові функиіональні властивості. Споживання розроблених комбінованих кулінарних виробів забезпечує добову потребу людини у вітаміні $C$ - на 19,5..39,5\%, $\beta$-каротині - на 28...67,6\%, у кальцію на 10,1...23,9\%, у флавоноїдах - на 32,6...56,3\% та білках у середньому на 27,6...46,5\%. Досліджені органолептичні та фізико-хімічні показники розробленої продукиї підтверджують доцільність використання білкових напівфабрикатів із зеленої маси сільськогосподарських і дикорослих рослин иукрового буряка, портулаку городнього, черемші в рецептурах комбінованих кулінарних виробів.

Ключові слова: білковмісні напівфабрикати, кулінарні вироби, зелена маса, амінокислотний склад.

Постановка проблеми. На сучасному етапі розвитку науки про харчування до збалансованості та повноцінності складу харчових продуктів висувається низка вимог: необхідним і обов'язковим $є$ повне забезпечення потреб організму не лише в енергії, есенціальних, мікро- і макронутрієнтах, але і в необхідних харчових волокнах і мінорних нехарчових біологічно активних компонентах їжі. Ці вимоги лежать в основі концепції оптимального харчу- 
вання. Саме таке харчування спроможне запобігти розвиткові хронічних неінфекційних захворювань[1]. В Україні у 2017 р. оновлено «Норми фізіологічних потреб населення України в основних харчових речовинах та енергії», де вперше введено норми споживання мінорних i біологічно активних речовин їжі із встановленою фізіологічною дією на організм (для дорослого населення) [2].

Харчування більшості українців можна охарактеризувати як нераціональне, розбалансоване, полідефіцитне. Це зумовлено низькою купівельною спроможністю населення, а також недостатніми знаннями та низьким рівнем культури харчування, шкідливими звичками, несприятливими екологічними умовами. В раціоні спостерігається дефіцит продуктів тваринного походження (молоко, м’ясо, риба, яйця), свіжої рослинної їжі (фрукти, овочі та інші рослини) i надлишок споживання тваринних жирів, хлібобулочних i борошняних виробів. У зв'язку з цим одним із важливих завдань учених-технологів є збагачення харчових продуктів есенціальними речовинами [3].

Сьогодні перспективним напрямом досліджень і технологічних розробок $\epsilon$ продукція для закладів ресторанного господарства. Так, важливу роль у раціоні харчування відіграють різноманітні кулінарні вироби, в яких поєднано сировину тваринного та рослинного походження - це крупеники, макаронники, фрикадельки, голубці, запіканки тощо. Існує низка технологій, що забезпечують виготовлення вказаних продуктів із максимальним збереженням корисних властивостей вихідної сировини. При цьому питання збалансованості та біологічної повноцінності вищезгаданої кулінарної продукції залишається невирішеним, адже загальновідомо, що недоліком традиційних м'ясо-рослинних кулінарних виробів $є$ їх низька біологічна цінність через низький вміст вітамінів антиоксидантного ряду, біофлавоноїдів та мінеральних речовин, а також незбалансованість амінокислотного складу. Також відомо, що всі види м’ясної сировини взагалі позбавлені або містять у незначній кількості такі необхідні функціональні інгредієнти, як харчові волокна, які сприяють прискореному виведенню з організму різноманітних канцерогенних і токсичних речовин [4; 5].

3 іншого боку, продукти на зерновій основі є джерелом основних нутрієнтів, в тому числі білків, складних вуглеводів, клітковини, вітамінів групи В та мінеральних речовин. Але при цьому рослинні білки зернових $\mathrm{i}$ продуктів їхньої переробки незбалансовані за складом, у зв’язку з чим монокомпонентні страви 3 них мають невисокі споживчі властивості. Аналізуючи амінокислотний склад сумарних білків різних злакових культур iз точки зору складу ідеального білка, необхідно відмітити, що всі вони, за винятком вівса, бідні на лізин, зокрема амінокислотний скор за лізином складає 45\% для манної крупи, 68\% для рисової та 76\% для гречаної, а за винятком рису і сорго - ізолейцином. Білки кукурудзи містять недостатню кількість триптофану (0,6\%). Амінокислотний скор за треоніном для вищезгаданих манної, рисової та гречаної круп складає 76, 86 та 79 \% відповідно. Тому під час розробки технології виробництва страв на основі злакової сировини їхня біологічна цінність може бути відрегульована шляхом комбінування компо- 
зиції та внесенням до рецептури компонентів-збагачувачів з високим вмістом лімітуючих амінокислот.

Тож найбільш перспективним шляхом вирішення проблеми збалансованості та біологічної повноцінності вищезгаданої кулінарної продукції $\epsilon$ створення багатокомпонентних виробів регульованого складу на основі комбінування сировини тваринного і рослинного походження.

Світовий і вітчизняний досвід свідчить про перспективність виробництва кулінарних виробів оздоровчої дії завдяки збагаченню їх натуральними білоквмісними добавками рослинного походження, наприклад, напівфабрикатами із зеленої маси рослин (в сухому, пастоподібному, пюреподібному вигляді). Окрім збалансованого за амінокислотним складом білка, вони містять у своєму складі низку функціональних інгредієнтів, які практично відсутні в продуктах тваринного походження: харчові волокна, ефірні олії, дубильні та ароматичні речовини, органічні кислоти, фітонциди, вітамін $\mathrm{C}, \beta$-каротин тощо[4; 6-8].

Мета дослідження: розроблення рецептур нових видів комбінованих кулінарних виробів, вивчення властивостей і поєднувальності компонентів, зокрема сировини тваринного і рослинного походження, а також якості отриманих виробів.

Матеріали і методи. Матеріалами для проведення досліджень є напівфабрикати, отримані із зеленої маси сільськогосподарських і дикорослих рослин, рецептури нових видів кулінарних виробів. Як контрольні зразки використано традиційні рецептури [9]: контроль № 1 - голубці з рисом і м'ясним фаршем; контроль № 2 - крупеник 3 крупи гречаної.

Визначення фізико-хімічних та органолептичних показників проводилося за загальноприйнятими методиками[10].

Результати і обговорення. На основі літературних даних і власних досліджень з'ясовано, що використання білковмісних напівфабрикатів із зеленої маси рослин під час приготування комбінованих кулінарних виробів $\epsilon$ одним із перспективних шляхів їх застосування як комплексних збагачувачів.

Білоквмісний напівфабрикат із зеленої маси рослин (БВН ЗМ) є продуктом, отриманим після низькотемпературного висушування зеленої маси цукрових (або столових буряків), портулаку городнього та черемші з подальшим змішуванням їх у певних співвідношеннях і помелом до розмірів часток 40-80 мкм. Отримана суміш являє собою дрібнодисперсний порошок яскравого зеленого кольору з часниковим запахом і присмаком та може використовуватись як збагачувач-емульгатор. За своїм хімічним складом БВН ЗМ містить близько $20-25 \%$ білків, збалансованих за вмістом незамінних амінокислот, легкозасвоюваних вуглеводів - до $20 \%$, клітковини - близько $8 \%$, а також органічні кислоти, мінеральні речовини, вітаміни, біофлавоноїди, аскорбінову кислоту, хлорофіли та каротиноїди, завдяки чому здатний виконувати роль імуномодулятора та антиокислювача, сприяти виведенню з організму радіонуклідів і важких металів та, як наслідок, надавати продуктам оздоровчо-профілактичних властивостей. Крім цього, використання у складі суміші листя черемші, що має достатньо виражені бактерицидні властивості, 
сприяє збереженню мікробіологічної безпеки продуктів, що нею збагачені, в процесі зберігання[11].

Методом комп'ютерного проектування з урахуванням нових теоретичних розробок у моделюванні амінокислотного складу харчових продуктів [12] розроблено рецептури комбінованих кулінарних виробів, наведені в табл. 1. Як натуральний білоквмісний збагачувач використано композиції порошкоподібних БВН із листя цукрового буряку, портулаку та черемші у співвідношенні $3,2: 1: 2,5$ (рецептура № 1) або БВН із листя цукрових буряків і черемші у співвідношенні 9:1(рецептура № 2).

\section{Таблиия 1. Рецептури комбінованих кулінарних виробів}

\begin{tabular}{|c|c|c|c|c|}
\hline \multirow{2}{*}{$\begin{array}{c}\text { Найменування } \\
\text { компонента }\end{array}$} & \multicolumn{5}{|c|}{ Кміст компонента, \% до маси виробу } \\
\hline Капуста свіжа & 53,0 & $49,0-49,5$ & - & Рецептура № 2 \\
\hline $\begin{array}{c}\text { Яловичина } \\
\text { (котлетне м’ясо) }\end{array}$ & 33,0 & $27,5-28,0$ & - & - \\
\hline $\begin{array}{c}\text { Сир } \\
\text { кисломолочний }\end{array}$ & - & - & 25,0 & $20,0-21,0$ \\
\hline Крупа рисова & 4,5 & $4,20-4,25$ & - & - \\
\hline Крупа гречана & - & - & 24,6 & $23,0-24,0$ \\
\hline Яйця & - & - & 1,67 & $3,1-3,25$ \\
\hline Сметана & - & - & 1,67 & $0,85-0,90$ \\
\hline Цибуля ріпчаста & 7,4 & $6,8-6,9$ & - & - \\
\hline $\begin{array}{c}\text { БВН ЗМ } \\
\text { Маргарин столовий }\end{array}$ & - & $3,3-3,5$ & - & $10,0-11,5$ \\
\hline $\begin{array}{c}\text { Сухарі } \\
\text { панірувальні }\end{array}$ & - & $1,90-1,95$ & 1,66 & $1,0-1,10$ \\
\hline Сіль харчова & - & $0,40-0,45$ & - & $0,95=1,0$ \\
\hline $\begin{array}{c}\text { Цукор } \\
\text { Перець чорний } \\
\text { мелений }\end{array}$ & - & - & 1,66 & $0,75-0,80$ \\
\hline $\begin{array}{c}\text { Вода для } \\
\text { відновлення }\end{array}$ & - & $0,04-0,05$ & - & $0,10-0,15$ \\
\hline
\end{tabular}

Результатом розв'язку оптимізаційної задачі стали варіанти рецептури (табл. 1), у яких передбачено внесення білоквмісного збагачувача у кількості $3,1 \ldots 3,3 \%$ та $10,0 \ldots 11,5 \%$ до маси готового виробу для голубців і крупеника відповідно.

У табл. 2 наведено результати визначення амінокислотного складу білків розроблених комбінованих кулінарних виробів порівняно з контрольними зразками.

Таблиця 2. Аналіз збалансованості амінокислотного складу білків у комбінованих кулінарних виробах

\begin{tabular}{|c|c|c|c|c|}
\hline & \multicolumn{4}{|c|}{ Зразки рецептур } \\
\cline { 2 - 5 } & Контроль № 1 & Рецептура № 1 & Контроль № 2 & Рецептура № 2 \\
\hline 1 & 2 & 3 & 4 & 5 \\
\hline \multicolumn{5}{|c|}{ Вміст амінокислот, г/100 г білку (амінокислотний скор, \%) } \\
\hline Лейцин & $7,66(109)$ & $7,62(109)$ & $10,49(150)$ & $8,04(115)$ \\
\hline Ізолейцин & $4,24(106)$ & $4,24(106)$ & $5,74(143)$ & $4,90(122)$ \\
\hline
\end{tabular}




\begin{tabular}{|c|c|c|c|c|}
\hline \multicolumn{5}{|c|}{ Продовження табл. 2} \\
\hline 1 & 2 & 3 & 4 & 5 \\
\hline Метіонін+цистин & $3,73(106)$ & $3,70(106)$ & $3,21(92)$ & $3,61(103)$ \\
\hline Лізин & $7,92(144)$ & $7,65(139)$ & $8,17(149)$ & $7,86(143)$ \\
\hline Фенілаланін+тирозин & $8,06(134)$ & $8,19(137)$ & $5,96(99)$ & $7,83(130)$ \\
\hline Треонін & $4,23(106)$ & $4,25(106)$ & $4,62(116)$ & $4,82(120)$ \\
\hline Валін & $5,47(109)$ & $5,41(108)$ & $5,82(116)$ & $5,37(107)$ \\
\hline Триптофан & $1,11(111)$ & $1,11(111)$ & $1,13(113)$ & $1,30(130)$ \\
\hline \multicolumn{5}{|c|}{ Коефіцієнт утилітарності амінокислотного складу $(U)$} \\
\hline$U, \%$ & 0,90 & 0,90 & 0,73 & 0,91 \\
\hline \multicolumn{5}{|c|}{ Коефіцієнт надлишковості незамінних амінокислот $\left(\sigma_{\text {над }}\right)$} \\
\hline$\sigma_{\text {над }}, \%$ & 4,10 & 3,89 & 13,26 & 4,34 \\
\hline
\end{tabular}

Аналіз збалансованості амінокислотного складу білків у розроблених кулінарних виробах засвідчив, що у випадку комбінування рослинної та тваринної сировини в рецептурі № 1 зберігається значення коефіцієнта утилітарності, а коефіцієнт надлишковості незамінних амінокислот навіть незначно зменшується на $0,20 \ldots 0,21 \%$ порівняно з контрольним зразком. Це дає змогу лише дещо зменшувати використання цінної тваринної сировини без погіршення біологічної цінності білкової складової кулінарної продукції. Збільшення в рецептурі вмісту білоквмісного напівфабрикату із зеленої маси призводить до погіршення біологічної цінності білкової складової кулінарного виробу. В рецептурі № 2 (крупеник із гречаної крупи) завдяки комбінації рослинної й тваринної сировини вдалося отримати збалансований амінокислотний склад розробленого кулінарного виробу та у 3 рази зменшити коефіцієнт надлишковості незамінних амінокислот.

Вивчено органолептичні показники якості готових комбінованих кулінарних виробів (табл. 3). Встановлено, що отримані за рецептурою № 1 кулінарні вироби, збагачені БВН, характеризуються більш високими органолептичними показниками порівняно з контрольним зразком за рахунок соковитості й гарної консистенції. Це можна пояснити так: з літературних джерел відомо, що наявність органічних кислот, якими багатий БВН із зеленої маси рослин, прискорює процес протеолізу білків м'яса, при цьому відбувається накопичення фізіологічно активних пептидів, змінюється молекулярна маса білка, збільшується його засвоюваність організмом людини. Також у результаті створення кислого середовища, коли значення $\mathrm{pH}$ знаходиться нижче за ізоелектричну точку основних білків м'язової тканини, зростає соковитість м'ясного фаршу, збільшується набухання колагену в кислому середовищі, знижується температура його денатурації, прискорюється процес перетворення в глютин, що сприяє підвищенню ніжності готового виробу [13]. У випадку використання рецептури № 2 отримано принципово новий смак крупеника гречаного порівняно із контрольним зразком. Це відбулося за рахунок заміни в традиційній рецептурі цукру на сіль і спеції з одночасним наданням крупенику пікантного часникового присмаку та аромату завдяки використанню черемші у складі збагачувача із зеленої маси рослин. Загалом, шляхом отримання якісної продукції з новими органолептичними показниками можна вирішити питання розширення асортименту комбінованих кулінарних виробів. 
Таблиия 3. Органолептична оцінка розроблених круп'яних кулінарних виробів

\begin{tabular}{|c|c|c|c|}
\hline \multirow{2}{*}{\multicolumn{2}{|c|}{ Показники якості }} & \multicolumn{2}{|c|}{ Найменування кулінарного виробу } \\
\hline & & \multirow{2}{*}{$\begin{array}{c}\text { Голубці з рисом і м'ясом } \\
\text { Форма циліндрична, } \\
\text { поверхня капусти - без } \\
\text { пошкоджень }\end{array}$} & \multirow{2}{*}{$\begin{array}{c}\text { Крупеник гречаний із сиром } \\
\begin{array}{c}\text { Рівномірно підсмажена } \\
\text { скоринка }\end{array}\end{array}$} \\
\hline Зовнішній вигляд & Характеристика & & \\
\hline & Оцінка, бали & 5,0 & 5,0 \\
\hline \multirow[t]{2}{*}{ Вигляд на розрізі } & характеристика & $\begin{array}{c}\text { фарш добре перемішаний } \\
\text { iз вкрапленнями частинок } \\
\text { цибулі та зелені }\end{array}$ & $\begin{array}{c}\text { Видно сир із вкрапленнями } \\
\text { зелені }\end{array}$ \\
\hline & Оцінка, бали & 5,0 & 5,0 \\
\hline \multirow[t]{2}{*}{ Смак } & Характеристика & $\begin{array}{c}\text { Соковитий, властивий } \\
\text { вихідним компонентам }\end{array}$ & $\begin{array}{c}\text { Властивий вихідним } \\
\text { компонентам }\end{array}$ \\
\hline & Оцінка, бали & 4,8 & 4,9 \\
\hline \multirow[t]{2}{*}{ Запах } & Характеристика & $\begin{array}{c}\text { Пряний з ароматом } \\
\text { часнику }\end{array}$ & Пряний з ароматом часнику \\
\hline & Оцінка, бали & 4,7 & 4,9 \\
\hline \multirow[t]{2}{*}{ Колір } & Характеристика & $\begin{array}{l}\text { Насичений зелений на } \\
\text { розрізі }\end{array}$ & $\begin{array}{c}\text { Сіро-коричневий з } \\
\text { салатовими вкрапленнями }\end{array}$ \\
\hline & Оцінка, бали & 5,0 & 4,7 \\
\hline \multirow[t]{2}{*}{ Консистенція } & Характеристика & $\begin{array}{c}\text { У готовому вигляді } \\
\text { соковита, нерозсипчаста }\end{array}$ & $\begin{array}{l}\text { М'яка, нерозсипчаста, } 3 \\
\text { хрусткою скоринкою }\end{array}$ \\
\hline & Оцінка, бали & 5,0 & 5,0 \\
\hline
\end{tabular}

У табл. 4 наведено якісні показники комбінованих кулінарних виробів. Слід відмітити, що в результаті внесення до рецептури білоквмісних напівфабрикатів із зеленої маси рослин можна не тільки забезпечити високу біологічну цінність харчових систем за рахунок комплементарності амінокислотного складу компонентів рослинного і тваринного походження, але й збільшити загальний вміст повноцінного білка (на $0,15 \ldots 3,7 \%$ ) 3 одночасним наданням продукції функціональних властивостей за рахунок збагачення ії біологічно активними речовинами.

Таблиця 4. Фізико-хімічні показники якості комбінованих кулінарних виробів

\begin{tabular}{|c|c|c|c|c|}
\hline Показник якості & Контроль № 1 & Рецептура № 1 & Контроль № 2 & Рецептура № 2 \\
\hline Масова частка вологи, \% & 70,3 & 71,2 & 55,9 & 57,1 \\
\hline Масова частка білку, \% & 7,9 & 8,05 & 8,8 & 12,51 \\
\hline Масова частка жиру, \% & 3,0 & 2,9 & 9,8 & 7,11 \\
\hline Масова частка вуглеводів, \% & 17,2 & 18,5 & 21,1 & 26,47 \\
\hline Енергетична цінність, ккал & 127,4 & 132,3 & 207,8 & 234,5 \\
\hline Вміст вітаміну С, мг\% & 1,4 & 6,5 & 0,24 & 10,6 \\
\hline Вміст кальцію, мг\% & 27,20 & 46,7 & 61,0 & 101,1 \\
\hline Вміст заліза, мг\% & 1,4 & 2,7 & 2,3 & 3,77 \\
\hline Вміст $\beta$-каротину, мг\% & 0,4 & 0,6 & 0,1 & 1,3 \\
\hline Вміст флавоноїдів, мг/100г & 5,6 & 33,8 & 6,2 & 54,1 \\
\hline
\end{tabular}

У табл. 5 проілюстровано ступінь забезпечення в основних фізіологічно функціональних інгредієнтах при вживанні однієї порції на добу розроблених кулінарних виробів дорослим населенням згідно з чинними нормами [2]. 
Таблиця 5. Рівень забезпечення добової потреби у фізіологічно функціональних інгредіснтах при вживанні однісї порції (П) кулінарних виробів

\begin{tabular}{|c|c|c|c|c|c|}
\hline \multirow{3}{*}{$\begin{array}{l}\text { Найменування } \\
\text { інгредієнта }\end{array}$} & \multirow{3}{*}{$\begin{array}{c}\text { Рекомендо- } \\
\text { ваний рівень } \\
\text { споживання }\end{array}$} & \multicolumn{4}{|c|}{ Задоволення добової потреби, \% } \\
\hline & & \multicolumn{2}{|c|}{$\begin{array}{c}\text { Голубці з рисом і м’ясом } \\
(П-240 \text { г) }\end{array}$} & \multicolumn{2}{|c|}{$\begin{array}{c}\text { Крупеник гречаний } \\
(\Pi-260 \text { г) }\end{array}$} \\
\hline & & контроль & розроблений & контроль & розроблений \\
\hline Білок & 70 г & $23,7-27,1$ & $24,2-27,6$ & $28,6-32,7$ & $40,7-46,5$ \\
\hline Кальцій & $1100-1200$ мг & $5,4-5,7$ & $9,3-10,1$ & $13,2-14,4$ & $21,91-23,9$ \\
\hline Залізо & $15-17 \mathrm{M \Gamma}$ & $19,8-22,4$ & $38,1-43,2$ & $35,2-39,9$ & $57,7-65,3$ \\
\hline Вітамін C & $70-80$ мг & $4,2-4,8$ & $19,5-22,3$ & $0,8-0,9$ & $34,5-39,5$ \\
\hline В-каротин & $5 \mathrm{M \Gamma}$ & 19,2 & 28 & 6 & 67,6 \\
\hline Флавоноїди & $250 \mathrm{м \Gamma}$ & 5,4 & 32,6 & 6,5 & 56,3 \\
\hline
\end{tabular}

Аналіз даних табл. 5 свідчить про загальне зростання ступеня забезпечення в основних фізіологічно функціональних інгредієнтах при вживанні однієї порції на добу розроблених кулінарних виробів порівняно $з$ традиційними. Варто відмітити, що, зважаючи на ступінь забезпечення білком i залізом при вживанні однієї порції на добу традиційних кулінарних виробів, ï можна віднести до функціональних. Внесення до проектованих рецептур білоквмісних напівфабрикатів із зеленої маси рослин дає змогу покращити цей показник. Так, за рівнем забезпечення добової потреби в білку маємо незначне зростання (лише на $0,5 \%$ ) для голубців з рисом і м'ясом, а для крупеника гречаного цей показник збільшується на $12,1 \ldots 13,8 \%$; за рівнем забезпечення добової потреби в залізі спостерігаємо зростання цього показника на $18,3 \ldots 20,8 \%$ та $22,5 \ldots 25,4 \%$ відповідно. Позитивним виявився той факт, що вироби, отримані за традиційними рецептурами, не мали достатнього для функціональних рівня інших фізіологічно функціональних інгредієнтів таких, як кальцій (для голубців), вітамін $\mathrm{C}, \beta$-каротин (для крупеника), флавоноїди. У нових виробів за рівнем забезпечення добової потреби в цих інгредієнтах спостерігаємо зростання досліджуваного показника для голубців і крупеника відповідно: по кальцію - в 1,8 та 1,65 раза; по вітаміну $\mathrm{C}-\mathrm{y}$ 4,6 та 44,2 раза; по $\beta$-каротину — у 1,5 та 11,3 раза; по флавоноїдах — у 6 та 8,7 раза. Тож із цих позицій можна стверджувати, що внесення до проектованих рецептур білоквмісних напівфабрикатів із зеленої маси рослин надає комбінованим кулінарним виробам додаткових функціональних властивостей.

\section{Висновки}

Під час розробки технології виробництва кулінарних виробів на основі комбінованої сировини їхня біологічна цінність може бути відрегульована шляхом отримання оптимального співвідношення та внесенням до рецептури компонентів-збагачувачів з високим вмістом лімітуючих амінокислот.

Створення комбінованих кулінарних виробів дасть змогу забезпечити населення доступним продуктом поліфункціональної дії та розширити асортимент кулінарної продукції.

\section{Література}

1. Філіпn'єва О. А. Раціональне харчування студентської молоді як складова здоров'я / О.А. Філіпп’єва // Наукові праці. Педагогіка. — 2012. — № 27. — С. 108-110. 
2. Наказ Міністерства охорони здоров’я України від 03 вересня 2017 року № 1073 «Про затвердження Норм фізіологічних потреб населення України в основних харчових речовинах та енергії», зареєстрований в Міністерстві юстиції України 02 жовтня 2017 року за № 1206/31074. — Режим доступу : http://zakon2.rada.gov.ua/laws/show/z1206-17/page\#n14.

3. Дружсинин П.В. Основи нутрициологии / П.В. Дружинин, Л.Ф. Новиков. - Москва : Высшая школа, 2010. - $150 \mathrm{c.}$

4. Пасічний В.M. Харчова цінність та функціонально-технологічні характеристики тваринної і рослинної сировини, що визначають якість м ясопродуктів / В.М. Пасічний // М'ясний бізнес. - 2009. - № 5. - С. $82-84$.

5. Пересічний M.I. Технологія продукції громадського харчування з використанням біологічно-активних добавок. Монографія / М.І. Пересічний, М.Ф. Кравченко, П.О. Карпенко. - Київ : КНТЕУ, 2003. - 322 с.

6. Евдокимова O.B. Инновационные технологии в разработке и продвижении на потребительский рынок функциональных продуктов питания [Текст] / О.В. Евдокимова, Е.В. Саватеев. - Под ред. Т.Н. Ивановой : монография. - Орел : ОГТУ, 2008. - 247 с.

7. Gupta S. Analysis of nutrient and antinutrient content of underutilized green leafy vegetables / S. Gupta, J.A. Lakshmi, M.N. Manjunath, J. Prakash // LWT Food Sci Technol. 2005. - V 38. - P. 339-345.

8. Просеков А.Ю. Научные основы производства продуктов питания: Учебное пособие / Кемеровский технологический институт пищевой промышленности. - Кемерово, 2005. $234 \mathrm{c}$.

9. Голунова Л.Е. Сборник рецептур блюд и кулинарных изделий для предприятий общественного питания. - Санкт-Петербург : Профи-информ, 2005. - 866 с.

10. Скурихин И.М. Руководство по методам анализа качества и безопасности пищевых продуктов / И.М. Скурихин, В.А. Тутельян. - Москва : Брандер-Медицина, 1998. - 380 с.

11. Патент UA 108159 МПК7 A 23 L 1/025, A 23 J 3/14, A 23 L 1/305. Спосіб отримання протеїновмісного збагачувача поліфункціональної дії з зеленої маси рослин. / Г.О. Сімахіна, Л.М. Солодко ; опубл. 25.03.2015р., Бюл. №6/2015.

12. Сімахіна Г.О. Вдосконалення теорії моделювання амінокислотного складу напівфабрикатів із зеленої маси рослин / Г.О. Сімахіна, В.С. Гуць, Л.М. Солодко // Наукові праці Національного університету харчових технологій. - 2017. - Том 23, № 4. - С. $244-251$.

13. Филонова О.В. Использование листа ревеня в производстве мясных полуфабрикатов // Актуальные проблемы технологии живых систем: Матер. междунар. научн.-техн. конференции молодых учених. - Владивосток, 2005. — С. 151-153. 